\title{
A Comprehensive Review on Human Aichi Virus
}

\author{
Enrique Rivadulla ${ }^{1} \cdot$ Jesús L. Romalde ${ }^{1}$
}

Received: 21 September 2019/ Accepted: 28 February 2020/Published online: 27 April 2020

(c) Wuhan Institute of Virology, CAS 2020, corrected publication 2020

\begin{abstract}
Although norovirus, rotavirus, adenovirus and Astrovirus are considered the most important viral agents transmitted by food and water, in recent years other viruses, such as Aichi virus (AiV), have emerged as responsible for gastroenteritis outbreaks associated with different foods. AiV belongs to the genus Kobuvirus of the family Picornaviridae. It is a virus with icosahedral morphology that presents a single stranded RNA genome with positive sense (8280 nucleotides) and a poly (A) chain. AiV was first detected from clinical samples and in recent years has been involved in acute gastroenteritis outbreaks from different world regions. Furthermore, several studies conducted in Japan, Germany, France, Tunisia and Spain showed a high prevalence of AiV antibodies in adults (between $80 \%$ and 99\%), which is indicative of a large exposure to this virus. The aim of this review is to bring together all the discovered information about the emerging pathogen human Aichi virus (AiV), discussing the possibles routes of transmission, new detection techniques and future research. Although $\mathrm{AiV}$ is responsible for a low percentage of gastroenteritis outbreaks, the high seroprevalence shown by human populations indicates an evident role as an enteric agent. The low percentage of AiV detection could be explained by the fact that the pathogen is more associated to subclinical infections. Further studies will be needed to clarify the real impact of $\mathrm{AiV}$ in human health and its importance as a causative gastroenteritis agent worldwide.
\end{abstract}

Keywords Human Aichivirus (AiV) $\cdot$ Kobuvirus $\cdot$ Picornaviridae $\cdot$ Gastroenteritis

\section{Introduction}

Acute gastroenteritis is the leading cause of morbidity worldwide especially among children under five years old and elderly population (Patel and Glass 2009). This is associated with important medical and healthcare costs. Foodborne viruses infect humans via gastrointestinal tracts and are excreted through feces, in a process known as fecal-oral route (Lee et al. 2013). Among these foodborne agents, norovirus (NoV), rotavirus (RV), adenovirus (AdV) and astrovirus (AsV) are considered the most important aetiological agents of acute non-bacterial gastroenteritis, transmitted by contaminated food and water (Phan et al. 2011; Amaral et al. 2015). Although nowadays the knowledge about viral foodborne diseases is extensive, the

Jesús L. Romalde

jesus.romalde@usc.es

1 Departamento de Microbiología y Parasitología, CIBUS-

Facultad de Biología, Universidade de Santiago de Compostela, 15782 Santiago, Spain study of fecal-oral route is relatively recent. The first documented outbreak associated with food was in 1914 , and the causative agent was recognized as poliovirus and transmitted through raw milk (Jubb 1915). This viral pathogen was later classified as a member of Picornaviridae family (Fenner 1976).

\section{History and Taxonomy}

The picornavirus term (pico: small; rna: ribonucleic acid) was first introduced in 1963. This viral family includes virus of small size with single-stranded RNA (ssRNA) as genetic material and contains many important human and animal pathogens (Melnick et al. 1963; Melnick 1996). The family Picornaviridae belongs to the order of Picornavirales and consists in 94 species grouped into 40 recognized genera (Fig. 1) (Adams et al. 2017; King et al. 2018).

Within all of these recognized genera, this review is focused on Kobuvirus. It was classified as a new genus in 1999 (King et al. 1999). The name comes from the 


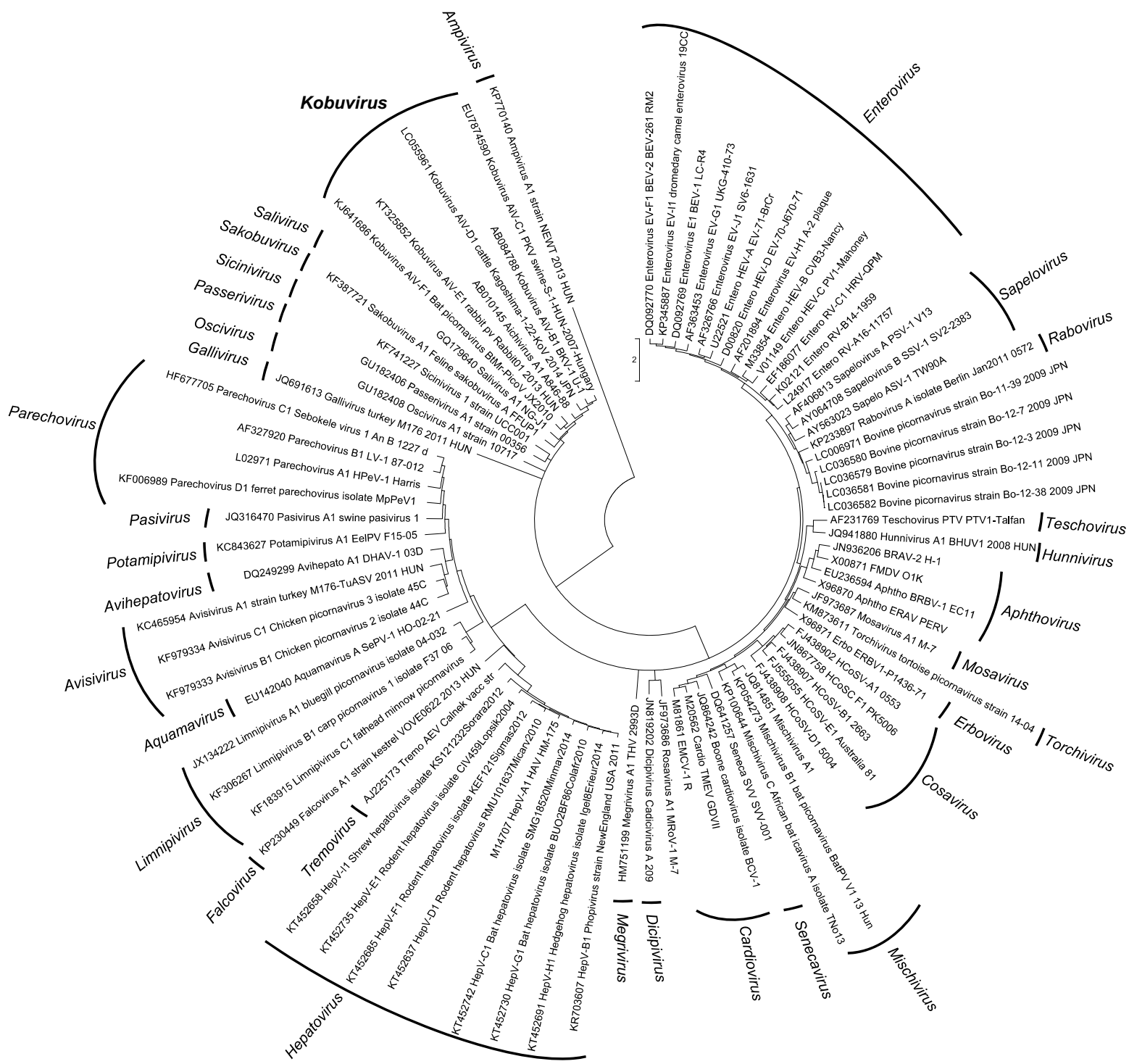

Fig. 1 Phylogenetic tree, based on the P1 protein gene, showing the relationships among members of the family Picornaviridae. The maximum likelihood tree was constructed using MEGA 7.6. GenBank accession numbers of the reference strains used are detailed in the tree.

Japanese word 'kobu' that means bump, and it refers to the characteristic morphology of the virion that appears bumpy at the electron microscope (Yamashita et al. 2000). The first three official candidates of Kobuvirus were Aichi virus, Bovine kobuvirus and Porcine kobuvirus which were described on the basis of the host in which the viruses were detected.

Nowadays, the genus Kobuvirus consists in six recently renamed species: Aichivirus A (formerly Aichi virus), Aichivirus $B$ (Bovine kobuvirus), Aichivirus $C$ (Porcine kobuviru), Aichivirus $D$ (kagovirus from black cattles), Aichivirus E (Rabbit picornavirus) and Aichivirus F (Bat kobuvirus) (Adams et al. 2017; Zell 2017). There are three tentative kobuviruses including caprine kobuvirus, Norway rat kobuvirus and a recovered viral genome from metagenomic sequences obtained from bat stool in Texas (USA) (Zell 2017).

Aichivirus $A$ is divided in six types: human Aichi virus (AiV) (Yamashita et al. 1991), canine kobuvirus (Kapoor et al. 2011; Barros et al. 2019), murine kobuvirus (Phan et al. 2011), Kathmandu sewage kobuvirus ( $\mathrm{Ng}$ et al. 2012), roller kobuvirus (Pankovics et al. 2014) and feline kobuvirus (Chung et al. 2013). The other species also display a certain degree of variability, 3 types having been described in Aichivirus $B$, and 2 types in the species Aichivirus $C$, Aichivirus $D$ and Aichivirus $F$. Finally, three genotypes (Fig. 2) have been described within human Aichi virus (named A to C) (Ambert-Balay et al. 2008).

$\mathrm{AiV}$ was first recognized and isolated in BSC-1 (kidney of normal adult African green monkey) cells in 1989 
Fig. 2 Phylogenetic tree, based on the P1 protein gene, showing the relationships among different genotypes of human AiV. The maximum likelihood tree was constructed using MEGA 7.6. GenBank accession numbers of the reference strains used are detailed in the tree.

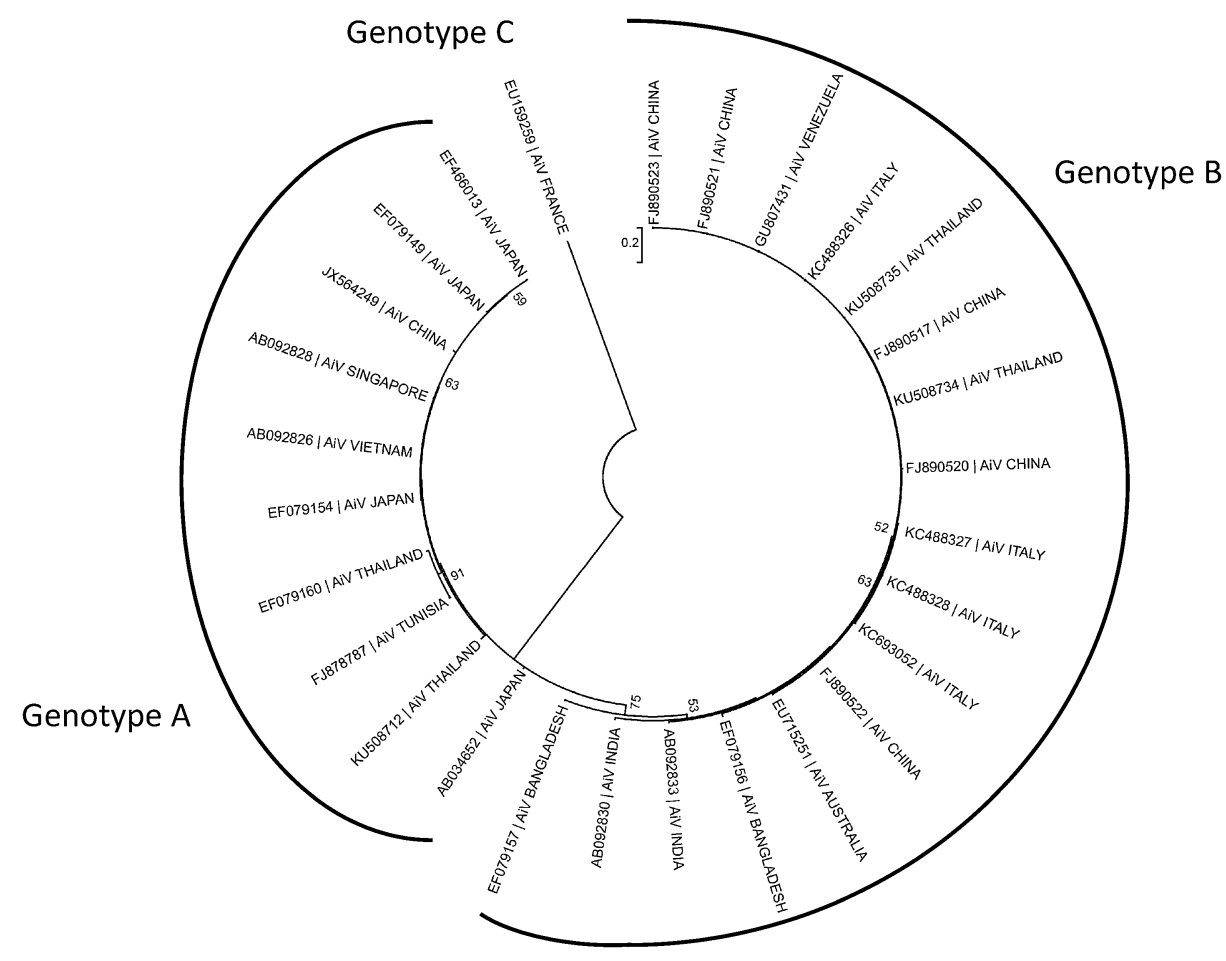

during the study of a gastroenteritis outbreak associated with oyster consumption in Japan (Yamashita et al. 1991, 1998). Some years later, in 1998, the complete genome sequence of AiV (GenBank accession no. AB040749) was described and classified as a novel picornavirus, at the Aichi Prefectural Institute of Public Health, in Japan (Yamashita et al. 2001). Outside Asia, the first detections of $\mathrm{AiV}$ in clinical specimens were reported in Europe (Germany) and South America (Brazil) (Oh et al. 2006).

\section{Physical Characteristics and Stability}

$\mathrm{AiV}$ is a small non-enveloped virus with icosahedral morphology. The virions show a rough surface with around $30 \mathrm{~nm}$ in diameter at the electron microscopy. The capsid reveals some surface depressions like "canyon" which form the site of receptor binding in many picornaviruses (Tuthill et al. 2010; Dang et al. 2014; Wang et al. 2012). In vitro, AiV shows stability in acid conditions as low as $\mathrm{pH} 2$ and is resistant to conventional methods of inactivation, including alcohols, heat, chlorine, high hydrostatic pressure, chloroform, non-ionic detergents and ether (Yamashita et al. 1998; Cromeans et al. 2014). Even more, AiV retained infectivity after 21 days at $4{ }^{\circ} \mathrm{C}$ in Cranberry juice and Cranberry juice cocktail ( $\mathrm{pH}$ 3.0) (Sewlikar and D'Souza 2017).

\section{Genomic Organization}

AiV has a ssRNA with positive sense (8280 nucleotides), composed by a $5^{\prime}$ untranslated region (UTR) of about 744 nucleotides with an internal ribosomal entry site (IRES) that allows direct translation of the polyprotein and a viral genomic protein $(\mathrm{VPg})$ instead of a methylated nucleotide cap structure; an open reading frame (ORF) followed by 237 nucleotides of a $3^{\prime}$ UTR region and a poly (A) tail (Fig. 3). The ORF is about $7.3 \mathrm{~kb}$ and encodes a polyprotein precursor of 2432 amino acids with a nonstructural leader $(\mathrm{L})$ protein at the $\mathrm{N}$-terminus, followed by viral capsid proteins P1 (VP0, VP3 and VP1) and, nonstructural proteins $\mathrm{P} 2(2 \mathrm{~A}, 2 \mathrm{~B}$ and $2 \mathrm{C})$ and $\mathrm{P} 3(3 \mathrm{~A}, 3 \mathrm{~B}, 3 \mathrm{C}$ and $3 \mathrm{D}$ ) that control the replication of $\mathrm{AiV}$ in the infected cells (Sabin et al. 2016; Zhu et al. 2016).

Capsid proteins adopt an eight-stranded antiparallel beta barrel configuration with a pseudo $T=3$ symmetry (where $T$ is the triangulation number), where VP0 and VP3 alternate about the two- and three-fold axes and VP1 surrounds the five-fold axes (Zhu et al. 2016). N-termini of the major capsid proteins are located inside of the capsid, and $\mathrm{C}$-termini are at the virion surface. The three capsid proteins were described with weights of 42,30 and $22 \mathrm{kDa}$ (Yamashita et al. 1998).

VP0 capsid protein remains in the mature particles of $\mathrm{AiV}$, in contrast with other picornaviruses. Also, the nonstructural protein $2 \mathrm{~A}$ and $\mathrm{L}$ protein have not shown 
Fig. 3 Schematic of the monopartite, linear, ssRNA (+) genome of $\mathrm{AiV}$

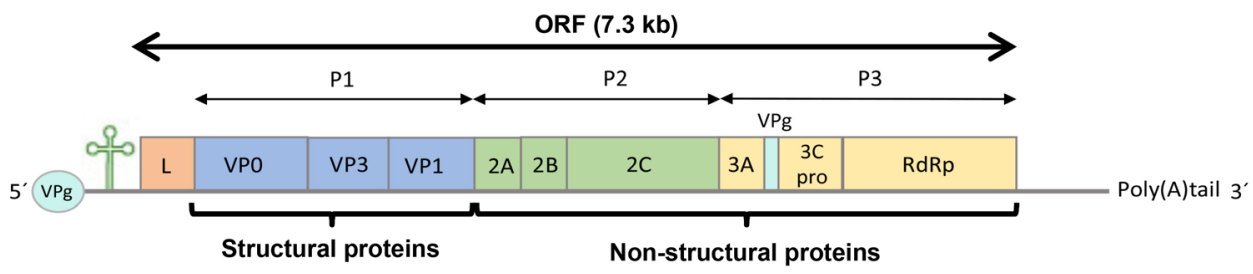

protease or autocatalytic motifs as are detected in other picornaviruses and their functions remain unclear (Yamashita et al. 1998; Buesa and Rodriguez-Díaz 2016). On the other hand, the $2 \mathrm{~A}$ protein contains conserved motifs that are charateistic of the H-rev107 family, which are involved in the cellular proliferation (Hughes and Stanway 2000). With regard to the other non-structural proteins, 2C, $3 \mathrm{C}$ and $3 \mathrm{D}$ regions are well aligned with the corresponding sequences of other picornavirus as Aphthovirus, Cardiovirus and Parechovirus. The 3B protein ( $\mathrm{VPg}$ ) of $\mathrm{AiV}$ is longer than other viruses of the same family, the $3 \mathrm{C}$ is the protease with conserved motifs characteristic of all picornaviruses, and the 3D region encodes the RNA-dependent RNA polymerase (RdRp) needed for viral replication (Yamashita and Sakae 2003). Furthermore, a complex formed with $2 \mathrm{~B}, 2 \mathrm{BC}, 2 \mathrm{C}, 3 \mathrm{~A}$, and $3 \mathrm{AB}$ proteins, Golgi apparatus protein $\mathrm{ACBD} 3$ and phosphatidylinositol 4-kinase III $\beta$ (PI4KB) at viral RNA replication sites, enhancing PI4KB-dependent phosphatidylinositol 4-phosphate (PI4P) production, is crucial for AiV replication (Klima et al. 2017; McPhail et al. 2017; Ishikawa-Sasaki et al. 2018).

\section{Viral Replication}

As other Picornaviridae members, AiV enter their host cells by receptor-mediated endocytosis (Fig. 4). After adsorption, the virus penetrates the cell through little known mechanisms that followed the stripping of virions and the release of viral RNA into the cytoplasm. Using ribosomes and other cellular proteins, the viral RNA (which is already mRNA), forms polyribosomes for the direct synthesis of a polyprotein.

The polyprotein is co- and post-translationally processed into the $\mathrm{L}$ protein, capsid proteins, mature nonstructural proteins and stable intermediates. These proteins modify the cellular environment and promote synthesis of RNA $(-)$ required for the complement RNA (+). When the protein combination increases, also increases the number of RNA (+) in the replicative complex that will be encapsidated after joining VPg (Belov 2016; van der Schaar et al. 2016).

As a preliminary step in the assembly, one of the cover precursors ( $\mathrm{P} 1)$ is cut by viral proteinases to form a $5 \mathrm{~S}$ subunit (immature promoter) composed of three protein aggregates (VP0, VP3 and VP1). The 5S subunit forms pentamers, 12 of which are required to form the 60 protein subunits of the capsid.

Once the maturation process has finished, the complete viral particles has 60 copies of each capsid protein, one copy of the RNA (+) genome and one copy of VPg; these often form crystals in the cytoplasm and are finally expelled to the outside by the lysis of the infected cell (Zell 2017).

\section{Molecular Characterization and Distribution}

Typing VP1 sequence is a suitable method for picornavirus classification (Oberste et al. 1999), but 3CD junction region has been also used for that purpose in $\mathrm{AiV}$ (Yamashita et al. 2000; Pham et al. 2007). A good correlation between both classifications has been reported for AiV genotypes (Ambert-Balay et al. 2008).

The first genetic differentiation of AiV genotypes was made by Yamashita et al. (2000). In that study the genetic relation among $17 \mathrm{AiV}$ isolates was predicted by the comparison of 519 bases at the putative junction between the $\mathrm{C}$ terminus of $3 \mathrm{C}$ and the $\mathrm{N}$ terminus of $3 \mathrm{D}$, and two groups were proposed: Group 1 or genotype A and group 2 or genotype B. Since then, 3 distinct genotype categories $\mathrm{A}, \mathrm{B}$ and $\mathrm{C}$ were described (Ambert-Balay et al. 2008; Kitajima and Gerba 2015). Furthermore, several studies suggest some geographical distribution of AiV genotypes (Fig. 5).

Among human population, the presence of genotype A has essentially been reported in Asian countries. Thus, AiV A was detected in samples connected with 12 out of 37 gastroenteritis outbreaks in Japan (Yamashita et al. 2000), most of them associated with oyster consumption, showing prevalences up to $81 \%$ (Table 1). In addition, AiV A was detected in stool samples from travelers with diarrhea returning from India, Nepal, Thailand, Indonesia, Singapore and Vietnam, reaching percentage values of almost $100 \%$ of genotyped samples (Yamashita and Sakae 2003). Further investigations also reported the same genotype in fecal samples negative for RV, AdV, NoV, Sapovirus and AsV from patients with acute gastroenteritis from Vietnam, Thailand and Bangladesh (Pham et al. 2007). 
Fig. 4 Schematic of the AiV life cycle.
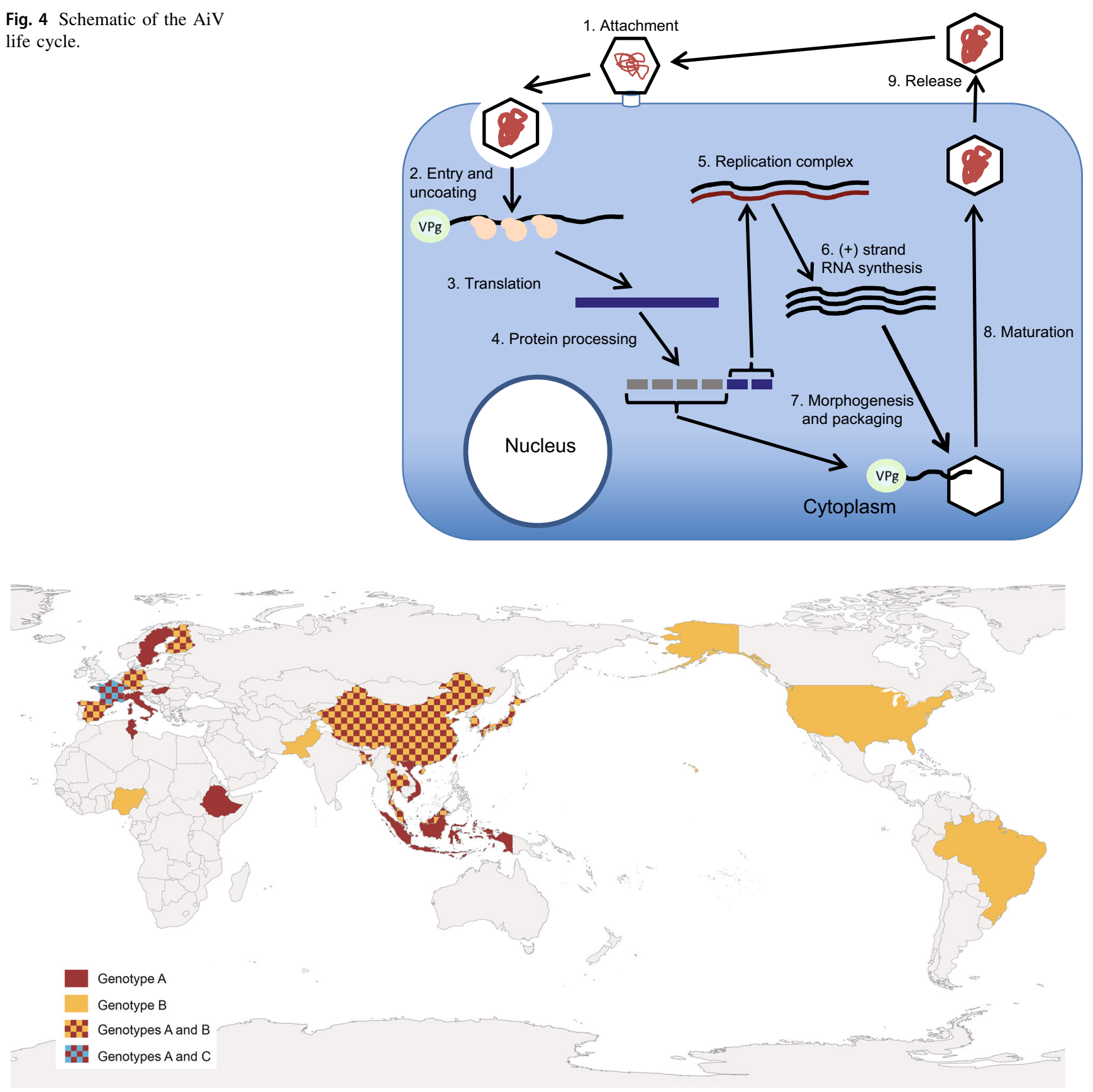

Fig. 5 Worldwide distribution of human AiV genotypes. Data from AiV related gastroenteritis outbreaks and environmental samples.

In Europe the presence of $\mathrm{AiV} \mathrm{A}$ was reported for the first time in Germany, from stool samples of patients involved in a gastroenteritis outbreak (Oh et al. 2006). Afterwards the same genotype was found in France, in samples from children and adults involved in gastroenteritis outbreaks and hospitalized for acute illness (AmbertBalay et al. 2008), in Finland from children under 5 years with gastroenteritis (Kaikkonen et al. 2010) and in a Hungarian sample from a 3 years old girl (Reuter et al.
2009). AiV A was also reported in elderly patients suffering from diarrhea, who were negative for AdV, RV, and calicivirus in Sweden (Jonsson et al. 2012) in Italy (Bergallo et al. 2017) and among different age groups from outpatients in Spain (Rivadulla et al. 2019). AiV A was also reported in Africa. It was detected in stool samples from inpatient and outpatient children collected in Monastir, Tunisia (Sdiri-Loulizi et al. 2009) and, more recently, 
Table 1 Features of the gastroenteritis outbreaks linked to $\mathrm{AiV}$.

\begin{tabular}{|c|c|c|c|c|c|c|}
\hline Country & Outbreak & Year & Source & Positive rate $(\%)^{\mathrm{a}}$ & Genotype & References \\
\hline \multirow[t]{12}{*}{ Japan } & 1 & 1987 & Oysters & 55.0 & A & \multirow[t]{12}{*}{ Yamashita et al. (2000) } \\
\hline & 2 & 1988 & Oysters & 71.4 & $\mathrm{~A}$ & \\
\hline & 3 & & Oysters & 81.8 & A & \\
\hline & 4 & 1989 & Oysters & 80.9 & $\mathrm{~A}$ & \\
\hline & 5 & & School meal & 64.3 & A & \\
\hline & 6 & 1990 & Oysters & 50.0 & $\mathrm{~B}$ & \\
\hline & 7 & & Oysters & 54.5 & A & \\
\hline & 8 & 1991 & Oysters & 50.0 & A & \\
\hline & 9 & 1994 & Oysters & 14.3 & A & \\
\hline & 10 & 1997 & Oysters & 62.5 & A & \\
\hline & 11 & 1998 & Oysters & 50.0 & A & \\
\hline & 12 & & Oysters & 33.0 & A & \\
\hline Germany & 1 & 2006 & $\mathrm{NS}^{\mathrm{b}}$ & NS & A & Oh et al. (2006) \\
\hline \multirow[t]{6}{*}{ France } & 1 & 2006 & Oysters & 50.0 & A & \multirow[t]{6}{*}{ Ambert-Balay et al. (2008) } \\
\hline & 2 & 2006 & Oysters & 50.0 & A & \\
\hline & 3 & & Oysters & 17.0 & A & \\
\hline & 4 & 2007 & Oysters & 100.0 & A & \\
\hline & 5 & & Oysters & 33.0 & A & \\
\hline & 6 & 2007 & Seafood $^{\mathrm{c}}$ & 6.0 & A & \\
\hline
\end{tabular}

${ }^{a}$ Numbers of fecal specimens positive/Numbers tested.

${ }^{\mathrm{b}} \mathrm{NS}$, not specified.

${ }^{\mathrm{c}}$ Shellfish species not specified. in young children with watery diarrhea in Ethiopia (Aiemjoy et al. 2019).

$\mathrm{AiV} \mathrm{B}$ was described at the same time as $\mathrm{AiV} \mathrm{A}$ in samples from Japan but with less prevalence (about $16 \%$ of samples were genotyped as B) (Yamashita et al. 2000). However, places like China, Pakistan, Bangladesh or Malaysia has been reported AiV B from patients with gastroenteritis, in higher percentages than AiV A (reaching percentages of up 100\%) (Pham et al. 2007; Yang et al. 2009; Li et al. 2017). On the other hand, in South Korea genotype prevalence is not clearly detected, since both genotypes were detected equally in stool samples from teenagers and adults (Han et al. 2014). In other places as Thailand, alternance of $\mathrm{AiV} \mathrm{A}$ and $\mathrm{AiV} \mathrm{B}$ as predominant genotypes along the time was observed (Yamashita et al. 2000; Saikruang et al. 2014; Chuchaona et al. 2017). In Europe, AiV B was also reported. In Finland and Spain AiV B was detected, but at lower prevalence than AiV A (Kaikkonen et al. 2010; Rivadulla et al. 2019). In Germany a genotype drift was detected, and AiV B seems to be more prevalent than in previous surveys (Drexler et al. 2011). AiV B was detected in stool samples from Brazilian children suffering diarrhea (Oh et al. 2006), and in North American children between 15 days and 5 years of age with symptoms of acute gastroenteritis (Chhabra et al.
2013). In Africa, AiV B was detected from one outpatient children in Nigeria (Japhet et al. 2018).

Only one survey reported AiV C from a stool sample of a child, hospitalized for gastroenteritis in France after a trip to Mali (Ambert-Balay 2008; Reuter et al. 2011). Further studies are needed to clarify the real impact of this genotype in human health.

Some investigations of in vivo evolution, based upon nt/ aa changes through the complete genome, have been performed for porcine kobuvirus suggesting good adaptation of the virus-host relationship (Reuter et al. 2011). Such research have not been carried out for human AiV yet, but it would be very helpful to understand the virus-species and host-species spectrums.

\section{Laboratory Diagnosis}

\section{Detection Methods}

Since AiV was discovered, various methods have been used to identify it (Table 2). Under electron microscopy, the viral particles have a distinct ultrastructure than other gastroenteritis pathogens as Sapovirus $(\mathrm{SaV})$ or $\mathrm{NoV}$, but there are not easy to distinguish from other small round viruses and could be wrongly be classified as an AsV 
(Yamashita et al. 1993). Although AiV have not shown cytopathic effect (CPE) in human cell lines as HeLa (Human cervix epitheloid carcinoma), HEL (Human Erythroleukemia Cell Line), RD (Human rhabdomyosarcoma Cell Line) cells or in newborn mice, AiV cause CPE on BSC-1 and Vero (both obtained from kidney of African green monkeys) cells (Yamashita et al. 1993). An enzymelinked immunosorbent assay (ELISA) was also developed for the detection of $\mathrm{AiV}$ antigens in clinical samples using monoclonal antibodies (Yamashita et al. 1993).

Reverse transcription-polymerase chain reaction (RTPCR) is a widely employed method for AiV research. It is a sensitive method applicable for further genetic analysis as genotyping (Yamashita et al. 2000). As mentioned before, the $3 C D$ junction region and VP1 region are suitable for differentiation of $\mathrm{AiV}$ genotypes. Nonetheless, no phylogenetic evidence of recombination has been reported between $\mathrm{AiV}$ genotypes $\mathrm{A}$ and $\mathrm{B}$, suggesting that both genotyping methods are reliable (Lukashev et al. 2012; Kitajima and Gerba 2015). Nested PCR targeting the 3C, VP1, and VP3 regions, as well as multiplex semi-nested PCR on VP0-VP3 region were also developed for genotyping (Oh et al. 2006; Lodder et al. 2013).

Recently, Oshiki et al. (2018) reported a high-throughput detection and genotyping tool for RNA virus, like AiV, using a microfluidic device and next-generation sequencer. In this study the investigators reported detection limits ranging from $10^{0}$ to $10^{3}$ copies/ $\mu \mathrm{L}$ in cDNA sample, corresponding to $10^{1}-10^{4}$ copies/mL-sewage, $10^{5}-10^{8}$ copies/g-human feces, and $10^{2}-10^{5}$ copies/g-digestive tissues of oyster. Simultaneous detection and genotyping techniques are powerful tools for source tracking of human pathogenic viruses.

A loop-mediated isothermal amplification procedure was developed by Lee and coworkers (Lee et al. 2019), for rapid and specific detection of $\mathrm{AiV}$ from water samples. The whole protocol can be performed in $2-8 \mathrm{~h}$ showing equivalent $\mathrm{AiV}$ detection than conventional PCR.

\section{Quantification Methods}

Although conventional culture methods like 50\% Tissue culture Infective Dose $\left(\mathrm{TCID}_{50}\right)$ are used to quantify AiV, methodological advances in molecular biology lead to the development of better technologies. Reverse transcriptionquantitative PCR (RT-qPCR) is nowadays the most employed method for $\mathrm{AiV}$ detection and quantification. The highly conserved $5^{\prime}$-UTR sequence is a common RTqPCR target for picornavirus detection (Drexler et al. 2011; Nielsen et al. 2013). However, a RT-qPCR that amplifies the VP0 region, and could quantify and differentiate between genotypes $\mathrm{A}$ and $\mathrm{B}$, was developed for determination of viral RNA load in clinical and environmental

Table 2 Laboratory diagnostic methods for AiV.

\begin{tabular}{|c|c|c|}
\hline $\begin{array}{l}\text { Laboratory } \\
\text { diagnostic method }\end{array}$ & Advantages & Disadvantages \\
\hline $\begin{array}{l}\text { Electron } \\
\text { microscopy }\end{array}$ & Visualization of viral particles & Labour and tedious. Useless for environmental samples \\
\hline Cell culture & $\begin{array}{l}\text { Variety of sensitive cell lines. Determination of } \\
\text { infectivity. Quantitative }\left(\text { TCID }_{50}\right)\end{array}$ & Labour and tedious. Effect of inhibitors/contaminants \\
\hline ELISA $^{\mathrm{a}}$ & Sensitivity. Especificity & Effect of inhibitors. Limited use for environmental samples \\
\hline $\mathrm{LAMP}^{\mathrm{b}}$ & $\begin{array}{l}\text { Sensitivity. Especificity. Rapidity. Isothermal } \\
\text { conditions }\end{array}$ & $\begin{array}{l}\text { Detection of infective and non-infective particles. Effect of } \\
\text { inhibitors }\end{array}$ \\
\hline RT-PCR ${ }^{c}$ & Sensitivity. Especificity. Rapidity & $\begin{array}{l}\text { Detection of infective and non-infective particles. Effect of } \\
\text { inhibitors }\end{array}$ \\
\hline RT-nested PCR & $\begin{array}{l}\text { Sensitivity. Especificity. Valid for genotyping coupled } \\
\text { with sequencing }\end{array}$ & $\begin{array}{l}\text { Detection of infective and non-infective particles. Effect of } \\
\text { inhibitors }\end{array}$ \\
\hline RT-qPCR ${ }^{d}$ & Sensitivity. Especificity. Rapidity. Quantification & $\begin{array}{l}\text { Detection of infective and non-infective particles. Need of } \\
\text { standard for quantification. Expensive }\end{array}$ \\
\hline Digital RT-PCR & $\begin{array}{l}\text { Sensitivity. Especificity. Rapidity. Absolute } \\
\text { quantification }\end{array}$ & $\begin{array}{l}\text { Detection of infective and non-infective particles. Hard } \\
\text { optimization. Expensive }\end{array}$ \\
\hline Pyrosequencing & Sensitivity. Universal detection & $\begin{array}{l}\text { Complex sample processing and bioinformatic analysis. } \\
\text { Expensive }\end{array}$ \\
\hline
\end{tabular}

${ }^{a}$ ELISA, enzyme-linked immunosorbent assay.

${ }^{\mathrm{b}}$ LAMP, loop-mediated isothermal amplification.

${ }^{\mathrm{c}} \mathrm{RT}$-PCR, reverse transcription-polymerase chain reaction.

${ }^{\mathrm{d}} \mathrm{RT}$-qPCR, real time quantitative RT-PCR. 
samples (Kitajima et al. 2013). This RT-qPCR consists in two amplifications: one that uses a universal primer pair that could amplify both genotypes and a universal probe to detect $\mathrm{AiV}$. The second one uses the same primer pair but two different genotype-specific probes. Both methods, VP0 qPCR and 5'-UTR qPCR showed similar efficiency for AiV detection, with the advantage that VP0 qPCR is able to quantify and also differentiate the AiV genotypes.

Although, these techniques have been helpful to clarify the transmission sources of $\mathrm{AiV}$ among population, during the recent years, new detection technologies have been developed. Digital RT-PCR (RT-dPCR) is a precise endpoint-sensitive absolute quantification approach, capable of determine the number of target copies without a standard curve. As an example, AiV and eighteen enteric viruses more were targeted with this method and compared with RT-qPCR (Coudray-Meunier et al. 2016), the conclusions were that the limit of $\mathrm{AiV}$ detection for RT-dPCR assay was lower $\left(7.8 \times 10^{2}\right.$ genome copies/ $\left.\mu \mathrm{L}\right)$ than the limit of detection obtained with conventional RT-qPCR $\left(1.0 \times 10^{3}\right.$ genome copies $/ \mu \mathrm{L})$. This new technology presents many advantages and possibilities for detection of enteric pathogens in environmental and clinical samples. The RTdPCR divides each reaction mix across thousands of individual PCR reactions, making this method more tolerant to inhibitory substances and also reducing the difficulty of virus quantification (Pinheiro et al. 2012; Rački et al. 2014).

\section{Clinical and Epidemiological Observations}

\section{Symptoms and Importance of Disease}

Gastrointestinal illness is commonly associated with symptoms produced by enteric viruses but usually masked for the presence of other pathogens (Yamashita and Sakae 2003). AiV replicates in the gastrointestinal tract, resulting usually in symptomless infections. Diarrhea, abdominal pain, nausea, vomiting and fever are the clinical symptoms but pathogenesis of $\mathrm{AiV}$ releases more in subclinical infections than in clinically manifest diseases (Yamashita et al. 1991, 2001). These subclinical infections do not need healthcare attention and underestimate the real impact of AiV in human health (Bergallo et al. 2017).

Nowadays, the clinical role of $\mathrm{AiV}$ as gastrointestinal pathogen stills unclear. Some surveys support the idea that $\mathrm{AiV}$ produce the outbreaks in coinfection with other viruses, because its frequent codetection with other enteric pathogens. This idea is also supported for the low incidence rates $(0.9 \%-4.1 \%)$ of $\mathrm{AiV}$ outbreaks (Kaikkonen et al. 2010; Jonsson et al. 2012; Nielsen et al. 2013). However, other studies showed high proportion of $\mathrm{AiV}$ monoinfections (Yang et al. 2009; Rivadulla et al. 2019), supporting the hypothesis that it is a gastrointestinal pathogen virulent enough to cause the need of medical are and hospitalization (Drexler et al. 2011; Chhabra et al. 2013).

When the illness appears is generally mild, lasting $48-72 \mathrm{~h}$ as is usual in this kind of enteric viruses (Carter 2005). AiV replicate and destroy the enterocyte layer covering the upper third of intestinal villi. That destruction of functional and mature cells interrupts the reabsorption of water and diarrhea ensues. As a response, villi get retracted and the absorption surface area decreases. Meanwhile, crypt cells undergo rapid division to repopulate the villi with immature cells resistant to the infection, but the younger cells can not replace the function of those that were infected because they require time to mature and diarrhea appears (Carter 2005). AiV is a cause of chronic infection in X-linked agammaglobulinemia and its prevalence in stool samples from patients with human immunodeficiency virus is high, indicating an opportunistic behavior in people with underlaying $\mathrm{T}$ cell defects (Oude Munnink et al. 2014; Portes et al. 2015; Bucciol et al. 2018).

The case of a Hungarian 3 years old girl is remarkable. The patient, positive for $\mathrm{AiV}$ (genotype A), showed rhinitis, purulent conjunctivitis and diarrhea and, after the first sampling day, she developed bronchopneumonia and fever with an elevated erythrocyte sedimentation rate (Reuter et al. 2009). In addition, the virus has also been associated with lower respiratory tract disease in Japan (Yamashita et al. 1993). These cases indicate the potential of AiV to cause extraintestinal disorders.

\section{Immunity}

Human AiV consists in one single serotype. Virological surveys suggest that $\mathrm{AiV}$ is responsible for a low percentage $(0.5 \%-1.8 \%)$ of gastroenteritis sporadic cases (Kitajima and Gerba 2015; Alcalá et al. 2018). However, high prevalence of antibodies against AiV (anti-AiV) was observed over the world.

The first seroprevalence study was carried out in Japan. In that survey the highest rate of anti-AiV was observed in adults of about 35 years old (Yamashita et al. 1993). Since then, several studies detected high levels of AiV seroprevalence worldwide and its correlation with the age of patients.

Several studies reported high percentages of AiV seroprevalence in Europe. In Germany, the percentages rise from $51 \%$, in children aged from 0 to 3 years, to almost $100 \%$, in patients $>40$ years old (Oh et al. 2006). Similar results were achieved in France, where these percentages increased steadily from $25 \%$ in infants between 7 months 
to 9 years old to $85 \%-90 \%$ in patients older than 40 years, with no significant variations among age groups after age 40 (Goyer et al. 2008). In Spain, a significant increase of anti-AiV was observed up to the age of 30 years old, with the absence of a significant increase after that age (Ribes et al. 2010). Also, in the same study the percentage of antiAiV observed was $100 \%$ in individuals over the age of 40 years old.

Serological studies carried out in Tunisia, revealed also a high prevalence of anti-AiV in humans of different age groups (Sdiri-Loulizi et al. 2009). As in the previous studies, the presence of anti-AiV throughout population increased with age raising from $68.8 \%$, in patients between 6 months and 10 years old, to $100 \%$ in elderly patients between 71 and 89 years old. This same study showed no significant variations in seroprevalence in patients $>30$ years old.

Considering all of these data, it is possible to conclude that the seroconversion to AiV occurs during childhood or adolescence, which may be indicating a role of $\mathrm{AiV}$ as a causative agent of pediatric diarrhea (Sdiri-Loulizi et al. 2009). Also, the high level of seroprevalence in adults showed in these surveys suggests a widespread exposure among human population to AiV.

\section{Environmental Occurrence}

\section{Wastewater}

AiV was identified in water in 2010 (Alcalá et al. 2010). Since then, AiV was reported in high percentages in wastewater samples around the world (Table 3). Current treatments applied in wastewater treatment plants (WWTPs), cannot guarantee a total removal of viral pathogens that are continuously discharged to the environment (da Silva et al. 2007).

In Japan $\mathrm{AiV}$ was detected in high percentages (from $66.2 \%$ to $100 \%$ ) in raw sewage samples, with viral concentrations ranging from $1.4 \times 10^{5}$ to $2.2 \times 10^{7}$ copies $/ \mathrm{L}$ (Yamashita et al. 2014; Kitajima et al. 2011, 2013). Samples of treated sewage also analyzed showed an AiV prevalence of $91.7 \%$ (Kitajima et al. 2011). AiV detection in sewage showed no seasonality, being detected throughout the year (Thongprachum et al. 2018). In other Asian countries, as Nepal, Thailand or Iran, AiV was also reported from untreated sewage samples ( $\mathrm{Ng}$ et al. 2012; Haramoto and Kitajima 2017; Azhdar et al. 2019). These studies supported the idea of use $\mathrm{AiV}$ as a human faecal pollution indicator, due its stability in wastewater and his lower removal percentages during wastewater treatments.

Other surveys detected AiV in Africa, America and Europe. In Africa, AiV was detected in Tunisia but at low prevalences. Thus, Sdiri-Loulizi et al. (2010) detected AiV in 10 out of $125(8 \%)$ samples of influent water samples and 4 out of $125(3.2 \%)$ treated sewage samples. On the other hand, Ibrahim et al. (2017) reported the virus in 51 out of $102(50 \%)$ samples. Moreover, a recent study carried out in South Africa detected AiV in 10 out of 12 pooled sewage samples (Onosi et al. 2019).

In USA, AiV was detected in a sample of untreated wastewater collected from Pennsylvania (Cantalupo et al. 2011). Furthermore, another study carried out in two WWTPs of southern Arizona, detected AiV in all influent and effluent samples, with viral levels of $1.2 \times 10^{4}$ to $4.0 \times 10^{6}$ copies/ $\mathrm{L}$ in influent samples and $2.0 \times 10^{3}-$ $4.0 \times 10^{5}$ copies $/ \mathrm{L}$ in effluent samples (Kitajima et al. 2014). A clear predominance of $\mathrm{AiV} B$ was revelaed in these positive samples (Kitajima et al. 2018).

Finally, in Europe the percentages of detection vary. AiV was observed in sewage samples from France, the Netherlands and Spain with detection rates between 61 and 100\% (Cantalupo et al. 2011; Lodder et al. 2013; Prevost et al. 2015). However, other analysis of untreated influent sewage samples collected from four WWTPs in Italy detected AiV in only $12.5 \%$ of the samples (Di Martino et al. 2013).

\section{River Water and Groundwater}

Surface water is infiltrated via spreading basins into aquifers and wells but, due to their small size and their survival capacity, viral pathogens like AiV are not totally removed during this natural filtration (Weiss 2005; Sharma and Amy 2010). Therefore, river water and groundwater are also possible reservoirs for AiV (Table 4).

Although AiV had been previously detected in tap water in USA (Rosario et al. 2009), the first study conducted to determine the occurrence and circulation of $\mathrm{AiV}$ in river water was carried out in Venezuela. In this study, AiV was detected in 5 out of 11 samples (45\%) (Alcalá et al. 2010). Other survey carried out in Japan for a longer period detected $\mathrm{AiV}$ in 36 out of 60 samples (60\%), demonstrating a higher detection frequency for $\mathrm{AiV}$ than for other enteric virus, like $\mathrm{NoV}$ or $\mathrm{SaV}$ is the same set of river samples (Kitajima et al. 2011). Hata et al. (2014), investigating the effects of rainfall events and water quality on viral occurrence, detected $\mathrm{AiV}$ in all the tested samples with relatively higher frequency of detection and concentration (ranging from $1.2 \times 10^{6}$ to $8.3 \times 10^{8}$ copies $/ \mathrm{L}$ ) than other enteric viruses. More recently, the same authors detected AiV in 20 out of 50 surface water samples in Japan (Hata et al. 2018).

In Nepal, AiV was detected from river water, groundwater, tap water in a house supplied by tanker water, and from a sewage pipe (Haramoto and Kitajima, 2017). In this 
Table 3 Worldwide detection of AiV in wastewater.

\begin{tabular}{|c|c|c|c|c|c|}
\hline Country $^{\mathrm{a}}$ & Positive Samples & Sample type & Genotype & Copies/L & References \\
\hline South Africa & $10 / 12$ & Raw sewage & NS & $N S^{b}$ & Onosi et al. (2019) \\
\hline \multirow[t]{3}{*}{ Tunisia } & $10 / 125$ & Raw sewage & A & NS & Sdiri-Loulizi et al. (2010) \\
\hline & $4 / 125$ & Treated sewage & A & NS & \\
\hline & $51 / 102$ & Raw sewage & $\mathrm{B}$ & NS & Ibrahim et al. (2017) \\
\hline \multirow[t]{3}{*}{ US } & $24 / 24$ & Raw sewage & $\mathrm{A}, \mathrm{B}$ & $1.2 \times 10^{4}-4.0 \times 10^{6}$ & Kitajima et al. $(2014,2018)$ \\
\hline & $24 / 24$ & Treated sewage & $\mathrm{A}, \mathrm{B}$ & $2.0 \times 10^{3}-4.0 \times 10^{5}$ & \\
\hline & $1 / 1$ & Raw sewage & NS & NS & Cantalupo et al. (2011) \\
\hline \multirow[t]{2}{*}{ Iran } & $7 / 10$ & Raw sewage & NS & $2.1 \times 10^{4}-1.9 \times 10^{6}$ & Azhdar et al. (2019) \\
\hline & $7 / 12$ & Treated sewage & NS & $4.2 \times 10^{3}-6.7 \times 10^{5}$ & \\
\hline \multirow[t]{6}{*}{ Japan } & $137 / 207$ & Raw sewage & A & NS & Yamashita et al. (2014) \\
\hline & $12 / 12$ & Raw sewage & $\mathrm{A}, \mathrm{B}$ & NS & Kitajima et al. (2011) \\
\hline & $11 / 12$ & Treated sewage & A & NS & \\
\hline & $12 / 12$ & Raw sewage & A & $1.4 \times 10^{5}-2.2 \times 10^{7}$ & Kitajima et al. (2013) \\
\hline & $11 / 12$ & Treated sewage & A & Up to $1.8 \times 10^{4}$ & \\
\hline & $11 / 12$ & Raw sewage & NS & NS & Thongprachum et al. (2018) \\
\hline \multirow[t]{2}{*}{ Nepal } & $1 / 1$ & Raw sewage & NS & NS & $\mathrm{Ng}$ et al. (2012) \\
\hline & $1 / 1$ & Raw sewage & B & NS & Haramoto and Kitajima (2017) \\
\hline Thailand & $1 / 1$ & Raw sewage & NS & NS & $\mathrm{Ng}$ et al. (2012) \\
\hline France & $61 / 100$ & Treated sewage & NS & Up to $10^{3}$ & Prevost et al. (2015) \\
\hline Italy & $6 / 48$ & Raw sewage & B & NS & Di Martino et al. (2013) \\
\hline Netherlands & $16 / 16$ & Raw sewage & A,B & NS & Lodder et al. (2013) \\
\hline Spain & $1 / 1$ & Raw sewage & NS & NS & Cantalupo et al. (2011) \\
\hline
\end{tabular}

${ }^{\mathrm{a}}$ Countries were ordered by continent and alphabetically within each continent.

${ }^{\mathrm{b}} \mathrm{NS}$, not specified.

Table 4 Worldwide detection of AiV in river, surface and ground waters.

\begin{tabular}{|c|c|c|c|c|c|}
\hline Country $^{\mathrm{a}}$ & Positive Samples & Sample type & Genotype & Copies/L & References \\
\hline \multirow[t]{2}{*}{ US } & $1 / 2$ & Reclaimed water & $N S^{b}$ & NS & Rosario et al. (2009) \\
\hline & $7 / 12$ & Ground water $^{\mathrm{b}}$ & NS & $1.0 \times 10^{2}-1.5 \times 10^{4}$ & Betancourt et al. (2014) \\
\hline Venezuela & $5 / 11$ & River water & B & NS & Alcalá et al. (2010) \\
\hline Iran & $15 / 28$ & River water & NS & $3.4 \times 10^{2}-5.9 \times 10^{6}$ & Azhdar et al. (2019) \\
\hline \multirow[t]{3}{*}{ Japan } & $36 / 60$ & River water & $A+B$ & NS & Kitajima et al. (2011) \\
\hline & $29 / 29$ & River water & NS & $8.6 \times 10^{2}-2.0 \times 10^{4}$ & Hata et al. (2014) \\
\hline & $20 / 52$ & Surface water & NS & Up to $10^{4}$ & Hata et al. (2018) \\
\hline \multirow[t]{3}{*}{ Nepal } & $14 / 14$ & River water & B & $1.2 \times 10^{6}-8.3 \times 10^{8}$ & Haramoto and Kitajima (2017) \\
\hline & $11 / 37$ & Ground water & B & $5.6 \times 10^{4}-2.0 \times 10^{6}$ & \\
\hline & $1 / 1$ & Tap water & B & $10^{9}$ & \\
\hline France & $20 / 175$ & River water & NS & Up to $10^{2}$ & Prevost et al. (2015) \\
\hline Netherlands & $12 / 14$ & River water & $A+B$ & NS & Lodder et al. (2013) \\
\hline
\end{tabular}

${ }^{\mathrm{a}}$ Countries were ordered by continent and alphabetically within each continent.

${ }^{\mathrm{b}} \mathrm{NS}$, not specified.

study, differences in $\mathrm{AiV}$ detection were observed, and a high prevalence of AiV B was reported. The frequence of AiV detection was significantly higher in shallow dug wells, where $\mathrm{AiV}$ was found in 10 out of 22 samples (45\%) than in shallow tube wells, in which AiV was found in 1 out of 15 samples (7\%). In accordance with the study, this could be happened due to the vulnerable structure of dug wells, which are usually made of brick or stone, than tube 
wells. On the other hand, a recent study from Iran reported the detection of $\mathrm{AiV}$ in $50 \%$ of the river water samples analyzed (Azhdar et al. 2019).

The first study for AiV detection in groundwater was performed in USA for the assessment of the occurrence and elimination of virus at a full-scale managed aquifer recharge system (Betancourt et al. 2014). In this study, the concentration of $\mathrm{AiV}$ was up to $1.52 \times 10^{4}$ copies/L. Recent environmental studies have demonstrated a high prevalence of $\mathrm{AiV}$ in different types of water samples, such as river and groundwater (Kitajima and Gerba 2015).

There are also some surveys that reported AiV from river samples in Europe. In France, 20 out of 175 river water samples were positive for $\mathrm{AiV}$ with up to $10^{2}$ copies/L concentration levels (Prevost et al. 2015). In the Netherlands, AiV was also detected in 12 out of 14 river water samples (Lodder et al. 2013). The importance of that pathogen in this kind of samples is not well understood and more investigation will be needed to evaluate the real impact of AiV. Recently, Bonadonna et al. (2019) reported for the first time the presence and abundance of AiV in marine bathing waters in the Adriatic and Tyrrhenian Seas (Italy).

\section{AIV in Shellfish}

Bivalve molluscs are associated with viral foodborne disease (Vossen 2001) as they obtain their food filtering small particles suspended in water. Often in these processes, molluscs concentrate and retain pathogens including enteric viruses (Romalde et al. 1994). These viruses are underestimated in molluscan safety controls that are based only on bacterial indicators, becoming this kind of food as a vector for enteric viruses transmission (Polo et al. 2015).

From its first detection, AiV has been suggested as an important etiological agent of gastroenteritis especially in outbreaks associated with contaminated seafood (Table 5) (Yamashita et al. 1991). In Japan, a one-year study carried out between 2005 and 2006, reported AiV A from clam samples, with a prevalence of $73 \%$ (Hansman et al. 2008).

Other studies reported AiV from shellfish samples worldwide. In Tunisia, Sdiri-Loulizi et al. (2010) reported an $\mathrm{AiV}$ prevalence of $4 \%$ in shellfish. Aditionally, the phylogenetic analysis revealed several clusters that occurred sequentially in time, pointing out some parallelism in the temporal shifts among environmental and human strains. On the other hand, Onosi et al. (2019) observed prevalence up to $66.6 \%$ in mussels from South Africa.

In France, other study detected AiV in oysters that were linked to a gastroenteritis outbreak and the AiV sequences obtained where similar to those from stool samples analyzed in parallel (Le Guyader et al. 2008). More recently, AiV has been detected from shellfish in Spain and Italy (Fusco et al. 2017; Rivadulla et al. 2017; Terio et al. 2018), with prevalence ranging from 1.7 to $12 \%$.

\section{Zoonotic Potential of Animal Kobuvirus}

As mentioned above, non-human Aichivirus have been described from different animal species, including some types of Aichivirus $A$, and those included in species Aichivirus $B$ to Aichivirus $F$. All of them had a standard picornavirus genome organization and sequence homology to human Aichivirus A (Otomaru et al. 2016), with the exception of Aichivirus $C$, which possesses a type IV IRES instead of the typical type V IRES present in the other Kobuvirus species.

Animal Kobuvirus can be transmitted directly by physical contact, or indirectly through water and food by the faecal-oral route (Reuter et al. 2011). Using Bayesian phylogenetic methods, evidences has been obtained for

Table 5 Worldwide detection of AiV in shellfish.

\begin{tabular}{|c|c|c|c|c|c|}
\hline Country $^{a}$ & Positive Samples & Sample type & Genotype & Copies/L & Reference \\
\hline South Africa & $8 / 12$ & Mussels & $\mathrm{NS}^{\mathrm{b}}$ & NS & Onosi et al. (2019) \\
\hline Tunisia & $4 / 60$ & Shellfish (NS) & A & NS & Sdiri-Loulizi et al. (2010) \\
\hline Japan & $19 / 26$ & Clams & A & NS & Hansman et al. (2008) \\
\hline France & $6 / 66$ & Oysters & NS & NS & Le Guyader et al. (2008) \\
\hline \multirow[t]{2}{*}{ Italy } & $13 / 108$ & Mussels & NS & Up to $10^{2}$ & Fusco et al. (2017) \\
\hline & $3 / 170$ & Mussels, Oysters, Clams & $\mathrm{A}, \mathrm{B}$ & NS & Terio et al. (2018) \\
\hline Spain & $15 / 249$ & Mussels, Clams, Cockles & NS & $\mathrm{NQ}^{\mathrm{c}}-6.9 \times 10^{3}$ & Rivadulla et al. (2017) \\
\hline
\end{tabular}

${ }^{\mathrm{a}}$ Countries were ordered by continent and alphabetically within each continent.

${ }^{\mathrm{b}} \mathrm{NS}$, not specified.

${ }^{\mathrm{c}} \mathrm{NQ}$, non quantifiable (under the limit of quantification of the method). 
transmission between different host taxa along Kobuvirus evolution, including host jumps from artiodactyla (sheep) to carnivora (ferret), from bats to rabbits, or from carnivora to birds and humans (Lu et al. 2018). In addition, evidences of zoonotic infection or interspecies transmission of bovine kouvirus to pig was documented (Kharim et al. 2010), suggesting that close contact among different animal species may increase the possibilities of interspecies transmission. However, further investigations over larger geographical scales and in other host species will be needed to clarify the evolutionary connections and host jumps.

\section{Concluding Remarks}

Since the first documented outbreak associated with food, it has become evident the importance of viruses as pathogens that cause alimentary illness. Also, the ineffectiveness of the current mechanisms of microbiological control in seafood, from a virological point of view, as well as the current vulnerability of our global food market are key factors in the appearance of outbreaks (Polo et al. 2010).

Our awareness of the risk associated to $\mathrm{AiV}$ as an etiological agent of gastroenteritis is increasing in the last years. As for other viruses, AiV stability allows its persistence stay in the environment for long periods, as well as its transmission to humans by ingestion of contaminated water and molluscs.

Although until now AiV is responsible for a low percentage of reported gastroenteritis outbreaks, the high seroprevalence shown by human populations indicates an evident role as an enteric agent. The low percentage of $\mathrm{AiV}$ detection could be explained by the lack of a routinary method for AiV screening, although the fact that the pathogen may be more associated to asymptomatic infections could not be ruled out. However, the methodological advances in molecular biology lead to the development of new technologies that improve the detection of these pathogens. Furthermore, these new methodologies are also lighting the investigation to clarify the transmission routes of AiV infection, solving the limitations of the classical detection methods.

In summary, further studies are needed in order to know the full spectrum of clinical symptoms of $\mathrm{AiV}$, as well as the burden of AiV disease in humans not only to improve our understanding of their clinical significance but also to determine the necessity of preventive measures, including specific vaccine development.

Acknowledgements Prof. Jesús L. Romalde acknowledges the support of Consellería de Educación, Universidade e Formación Profesional, Xunta de Galicia, Spain (Grant 2014-PG110), that funded the research that generated part of the results presented here.

\section{Compliance with Ethical Standards}

Conflict of interest The authors declare that they have no conflict of interest.

Animal and Human Rights Statement This article does not contain any studies with human or animal subjects performed by any of the authors.

\section{References}

Adams MJ, Lefkowitz EJ, King AMQ, Harrach B, Harrison RL, Knowles NJ, Kropinski AM, Krupovic M, Kuhn JH, Mushegian AR, Nibert M, Sabanadzovic S, Sanfaçon H, Siddell SG, Simmonds P, Varsani A, Zerbini FM, Gorbalenya AE, Davison AJ (2017) Changes to taxonomy and the International Code of Virus Classification and Nomenclature ratified by the International Committee on Taxonomy of Viruses (2017). Arch Virol 162:2505-2538. https://doi.org/10.1007/s00705-017-3358-5

Aiemjoy K, Altan E, Aragie S, Fry DM, Phan TG, Deng X, Chanyalew M, Tadesse Z, Callahan EK, Delwart E, Keenan JD (2019) Viral species richness and composition in young children with loose or watery stool in Ethiopia. BMC Infect Dis 19(242-246):53. https://doi.org/10.1186/s12879-019-3674-3

Alcalá A, Vizzi E, Rodríguez-Díaz J, Zambrano JL, Betancourt W, Liprandi F (2010) Molecular detection and characterization of Aichi viruses in sewage polluted waters of Venezuela. Appl Environ Microbiol 76:4113-4115. https://doi.org/10.1128/AEM. 00501-10

Alcalá AC, Pérez K, Blanco R, González R, Ludert JE, Liprandi F, Vizzi E (2018) Molecular detection of human enteric viruses circulating among children with acute gastroenteritis in Valencia, Venezuela, before rotavirus vaccine implementation. Gut Pathog 10:6. https://doi.org/10.1186/s13099-018-0232-2

Amaral MS, Estevam GK, Penatti M, Lafontaine R, Lima IC, Spada PK, Gabbay YB, Matos NB (2015) The prevalence of norovirus, astrovirus and adenovirus infections among hospitalised children with acute gastroenteritis in Porto Velho, State of Rondônia, western Brazilian Amazon. Mem Inst Oswaldo Cruz 110:215-221. https://doi.org/10.1590/0074-02760140381

Ambert-Balay K, Lorrot M, Bon F, Giraudon H, Kaplon J, Wolfer M, Lebon P, Gendrel D, Pothier P (2008) Prevalence and genetic diversity of Aichi virus strains in stool samples from the community and hospitalized patients. J Clin Microbiol 46:1252-1258. https://doi.org/10.1128/JCM.02140-07

Azhdar Z, Ghaderi M, Mousavi-Nasab SD (2019) Optimization of RT-qPCR for detection of Aichi virus in sewage and river water samples in Karaj, Iran. Arch Iran Med 22(5):242-246

Barros BCV, Castro CMO, Pereira D, Ribeiro LG, Júnior JWBD, Casseb SMM, Holanda GM, Cruz ACR, Júnior ECS, Mascarenhas JDP (2019) Proposed new strain of canine kobuvirus from fecal samples of Brazilian domestic dogs. Microbiol Resour Announc 8:e01292-e012918. https://doi.org/10.1128/MRA. 01292-18

Belov GA (2016) Dynamic lipid landscape of picornavirus replication organelles. Curr Opin Virol 19:1-6. https://doi.org/10.1016/j. coviro.2016.05.003

Bergallo M, Galliano I, Montanari P, Rassu M, Daprà V (2017) Aichivirus in children with Diarrhea in Northern Italy. Intervirology 60:196-200. https://doi.org/10.1159/000487051

Betancourt WQ, Kitajima M, Wing AD, Regnery J, Drewes JE, Pepper IL, Gerba CP (2014) Assessment of virus removal by managed aquifer recharge at three full-scale operations. J Environ Sci Health, Part A 49 (14):1685-1692 
Bonadonna L, Briancesco R, Suffredini E, Coccia A, Della Libera S, Carducci A, Verani M, Federigi I, Iaconelli M, Bonanno Ferraro G, Mancini P, Veneri C, Ferretti E, Lucentini L, Gramacioni L, La Rosa G (2019) Enteric viruses, somatic coliphages and Vibrio species in marine bathing and non-bathing waters in Italy. Mar Poll Bull 149:110507. https://doi.org/10.1016/j.marpolbul.2019. 110507

Bucciol G, Moens L, Payne K, Wollants E, Mekahli D, Levtchenko E, Vermeulen F, Tousseyn T, Gray P, Ma CS, Tangye SG, Van Ranst M, Brown JR, Breuer J, Meyts I (2018) Chronic Aichi virus infection in a patient with X-linked agammaglobulinemia. J Clin Immunol 38:938-939. https://doi.org/10.1007/s10875018-0558-z

Buesa J, Rodriguez-Díaz J (2016) The molecular virology of enteric viruses. In: Goyal S, Cannon J (eds) Viruses in foods. Food microbiology and food safety. Springer, Cham, pp 59-130. https://doi.org/10.1007/978-3-319-30723-7_3

Cantalupo PG, Calgua B, Zhao G, Hundesa A, Wier AD, Katz JP, Grabe M, Hendrix RW, Girones R, Wang D, Pipas JM (2011) Raw sewage harbors diverse viral populations. MBiol 2:e0018011. https://doi.org/10.1128/mBio.00180-11

Carter MJ (2005) Enterically infecting viruses: pathogenicity, transmission and significance for food and waterborne infection. J Appl Microbiol 98:1354-1380. https://doi.org/10.1111/j.13652672.2005.02635.x

Chhabra P, Payne DC, Szilagyi PG, Edwards KM, Staat MA, Shirley SH, Wikswo M, Nix WA, Lu X, Parashar UD, Vinjé J (2013) Etiology of viral gastroenteritis in children $<5$ years of age in the United States, 2008-2009. J Infect Dis 208:790-800. https:// doi.org/10.1093/infdis/jit254

Chuchaona W, Khamrin P, Yodmeeklin A, Kumthip K, Saikruang W, Thongprachum A, Okitsu S, Ushijima H, Maneekarn N (2017) Detection and characterization of Aichi virus 1 in pediatric patients with diarrhea in Thailand. J Med Virol 89:234-238. https://doi.org/10.1002/jmv.24630

Chung JY, Kim SH, Kim YH, Lee MH, Lee KK, Oem JK (2013) Detection and genetic characterization of feline kobuviruses. Virus Genes 47:559-562. https://doi.org/10.1007/s11262-0130953-8

Coudray-Meunier C, Fraisse A, Martin-Latil S, Delannoy S, Fach P, Perelle S (2016) A novel high-throughput method for molecular detection of human pathogenic viruses using a nanofluidic realtime PCR system. PLoS ONE 11:e0147832. https://doi.org/10. 1371/journal.pone.0147832

Cromeans T, Park GW, Costantini V, Lee D, Wang Q, Farkas T, Lee A, Vinjé J (2014) Comprehensive comparison of cultivable norovirus surrogates in response to different inactivation and disinfection treatments. Appl Environ Microbiol 80:5743-5751. https://doi.org/10.1128/AEM.01532-14

da Silva AK, Le Saux JC, Parnaudeau S, Pommepuy M, Elimelech M, Le Guyader FS (2007) Evaluation of removal of noroviruses during wastewater treatment, using real-time reverse transcription-PCR: different behaviors of genogroups I and II. Appl Environ Microbiol 73:7891-7897. https://doi.org/10.1128/AEM. 01428-07

Dang M, Wang X, Wang Q, Wang Y, Lin J, Sun Y, Li X, Zhang L, Lou Z, Wang J, Rao Z (2014) Molecular mechanism of SCARB2-mediated attachment and uncoating of EV71. Protein Cell 5:692-703. https://doi.org/10.1007/s13238-014-0087-3

Di Martino B, Di Profio F, Ceci C, Di Felice E, Marsilio F (2013) Molecular detection of Aichi virus in raw sewage in Italy. Arch Virol 158:2001-2005. https://doi.org/10.1007/s00705-013-16947

Drexler JF, Baumgarte S, de Souza Luna LK, Eschbach-Bludau M, Lukashev AN, Drosten C (2011) Aichi virus shedding in high concentrations in patients with acute diarrhea. Emerg Infect Dis 17:1544-1548. https://doi.org/10.3201/eid1708.101556

Fenner F (1976) The classification and nomenclature of viruses. J Gen Virol 31:463-470. https://doi.org/10.1099/0022-1317-31-3-463

Fusco G, Di Bartolo I, Cioffi B, Ianiro G, Palermo P, Monini M, Amoroso MG (2017) Prevalence of foodborne viruses in mussels in Southern Italy. Food Environ Virol 9:187-194. https://doi.org/ 10.1007/s12560-016-9277-x

Goyer M, Aho LS, Bour JB, Ambert-Balay K, Pothier P (2008) Seroprevalence distribution of Aichi virus among a French population in 2006-2007. Arch Virol 153:1171-1174. https:// doi.org/10.1007/s00705-008-0091-0

Han TH, Park SH, Hwang ES, Reuter G, Chung JY (2014) Detection of Aichi virus in South Korea. Arch Virol 159:1835-1839. https://doi.org/10.1007/s00705-014-2006-6

Hansman GS, Oka T, Li TC, Nishio O, Noda M, Takeda N (2008) Detection of human enteric viruses in Japanese clams. J Food Prot 71:1689-1695

Haramoto E, Kitajima M (2017) Quantification and genotyping of Aichi virus 1 in water samples in the Kathmandu Valley, Nepal. Food Environ Virol 9:350-353. https://doi.org/10.1007/s12560017-9283-7

Hata A, Katayama H, Kojima K, Sano S, Kasuga I, Kitajima M, Furumai H (2014) Effects of rainfall events on the occurrence and detection efficiency of viruses in river water impacted by combined sewer overflows. Sci Total Environ 468-469:757-763. https://doi.org/10.1016/j.scitotenv.2013.08.093

Hata A, Hanamoto S, Ihara M, Shirasaka Y, Yamashita N, Tanaka H (2018) Comprehensive study on enteric viruses and indicators in surface water in Kyoto, Japan, during 2014-2015 season. Food Environ Virol 10:353-364. https://doi.org/10.1007/s12560-0189355-3

Hughes PJ, Stanway G (2000) The 2A proteins of three diverse picornaviruses are related to each other and to the H-rev107 family of proteins involved in the control of cell proliferation. J Gen Virol 81:201-207. https://doi.org/10.1099/0022-1317-81$1-201$

Ibrahim C, Hammami S, Mejri S, Mehri I, Pothier P, Hassen A (2017) Detection of Aichi virus genotype B in two lines of wastewater treatment processes. Microb Pathog 109:305-312. https://doi. org/10.1016/j.micpath.2017.06.001

Ishikawa-Sasaki K, Nagashima S, Taniguchi K, Sasaki J (2018) Model of OSBP-mediated cholesterol supply to Aichi virus RNA replication sites involving protein-protein interactions among viral proteins, ACBD3, OSBP, VAP-A/B, and SAC1. J Virol 92:e01952-17. https://doi.org/10.1128/JVI.01952-17

Japhet MO, Famurewa O, Adesina OA, Opaleye OO, Wang B, Höhne M, Bock CT, Mas Marques A, Niendorf S (2018) Viral gastroenteritis among children of $0-5$ years in Nigeria: characterizaion of the first Nigerian aichivirus, recombinant noroviruses and detection of a zoonotic astrovirus. J Clin Virol 111:4-11. https://doi.org/10.1016/j.jcv.2018.12.004

Jonsson N, Wahlström K, Svensson L, Serrander L, Lindberg AM (2012) Aichi virus infection in elderly people in Sweden. Arch Virol 157(7):1365-1369. https://doi.org/10.1007/s00705-0121296-9

Jubb G (1915) A third outbreak of epidemic poliomyelitis at west kirby. The Lancet 185:67. https://doi.org/10.1016/S01406736(01)63665-1

Kaikkonen S, Räsänen S, Rämet M, Vesikari T (2010) Aichi virus infection in children with acute gastroenteritis in Finland. Epidemiol Infect 138:1166-1171. https://doi.org/10.1017/ S0950268809991300

Kapoor A, Simmonds P, Dubovi EJ, Qaisar N, Henriquez JA, Medina J, Shields S, Lipkin WI (2011) Characterization of a canine 
homolog of human Aichivirus. J Virol 85:11520-11525. https:// doi.org/10.1128/JVI.05317-11

Kharim P, Maneekarn N, Hidaka S, Kishikawa S, Ushijima K, Okitsu S, Ushijima H (2010) Molecular dtection of kobuvirus sequences in stool samples collected from healthy pigs in Japan. Infrect Genet Evol 10:950-954. https://doi.org/10.1016/j.meedid.2010. 06.001

King AMQ, Brown F, Christian P, Hovi T, Hyypiä T, Knowles NJ, Lemon SM, Minor PD, Palmenberg AC, Skern T, Stanway G (1999) Picornaviridae. In: Van Regenmortel MHV, Fauquet CM, Bishop DHL, Calisher CH, Carsten EB, Estes MK, Lemon SM, Maniloff J, Mayo MA, McGeoch DJ, Pringle CR, Wickner RB (eds) Virus taxonomy. Seventh Report of the International Committee for the Taxonomy of Viruses, Academic Press, NewYork, San Diego, pp 657-673

King AMQ, Lefkowitz EJ, Mushegian AR, Adams MJ, Dutilh BE, Gorbalenya AE, Harrach B, Harrison RL, Junglen S, Knowles NJ, Kropinski AM, Krupovic M, Kuhn JH, Nibert ML, Rubino L, Sabanadzovic S, Sanfaçon H, Siddell SG, Simmonds P, Varsani A, Zerbini FM, Davison AJ (2018) Changes to taxonomy and the international code of virus classification and nomenclature ratified by the international committee on taxonomy of viruses (2018). Arch Virol 163:2601-2631. https://doi. org/10.1007/s00705-018-3847-1

Kitajima M, Gerba CP (2015) Aichi virus 1: environmental occurrence and behavior. Pathogens 4:256-268. https://doi.org/10. 3390/pathogens 4020256

Kitajima M, Haramoto E, Phanuwan C, Katayama H (2011) Prevalence and genetic diversity of Aichi viruses in wastewater and river water in Japan. Appl Environ Microbiol 77:2184-2187. https://doi.org/10.1128/AEM.02328-10

Kitajima M, Hata A, Yamashita T, Haramoto E, Minagawa H, Katayama H (2013) Development of a reverse transcriptionquantitative PCR system for detection and genotyping of Aichi viruses in clinical and environmental samples. Appl Environ Microbiol 79:3952-3958. https://doi.org/10.1128/AEM.0082013

Kitajima M, Iker BC, Pepper IL, Gerba CP (2014) Relative abundance and treatment reduction of viruses during wastewater treatment processes-identification of potential viral indicators. Sci Total Environ 488-489:290-296. https://doi.org/10.1016/j. scitotenv.2014.04.087

Kitajima M, Rachmadi AT, Iker BC, Haramoto E, Gerba CP (2018) Temporal variations in genotype distribution of human sapoviruses and Aichi virus 1 in wastewater in Southern Arizona, United States. J Appl Microbiol 124:1324-1332. https://doi.org/ 10.1111/jam.13712

Klima M, Chalupska D, Różycki B, Humpolickova J, Rezabkova L, Silhan J, Baumlova A, Dubankova A, Boura E (2017) Kobuviral non-structural $3 \mathrm{~A}$ proteins act as molecular harnesses to hijack the host ACBD3 protein. Structure 25:219-230. https://doi.org/ 10.1016/j.str.2016.11.021

Le Guyader FS, Le Saux JC, Ambert-Balay K, Krol J, Serais O, Parnaudeau S, Giraudon H, Delmas G, Pommepuy M, Pothier P, Atmar RL (2008) Aichi virus, norovirus, astrovirus, enterovirus, and rotavirus involved in clinical cases from a French oysterrelated gastroenteritis outbreak. J Clin Microbiol 46:4011-4017. https://doi.org/10.1128/JCM.01044-08

Lee RM, Lessler J, Lee RA, Rudolph KE, Reich NG, Perl TM, Cummings DA (2013) Incubation periods of viral gastroenteritis: a systematic review. BMC Infect Dis 13:446. https://doi.org/10. 1186/1471-2334-13-446

Lee JY, Kim JH, Rho JY (2019) Development of rapid and specific detection for the human Aichivirus A using the loop-mediated isothermal amplification from water samples. Indian J Microbiol 59:375-378. https://doi.org/10.1007/s12088-019-00803-3
Li LL, Liu N, Yu JM, Ao YY, Li S, Stine OC, Duan ZJ (2017) Analysis of Aichi virus and Saffold virus association with pediatric acute gastroenteritis. J Clin Virol 87:37-42. https://doi. org/10.1016/j.jcv.2016.12.003

Lodder WJ, Rutjes SA, Takumi K, de Roda Husman AM (2013) Aichi virus in sewage and surface water, The Netherlands. Emerg Infect Dis 19:1222-1230. https://doi.org/10.3201/ eid1908.130312

Lu L, Van Dung N, Ivens A, Bogaardt C, O’Toole A, Bryant JE, Carrique-Mas J, Van Cuong N, Anh PH, Rabaa MA, Tue NT, Thwaites GE, Baker S, Simmonds P, Woolhouse ME, VIZIONS Consortium (2018) Genetic diversity and cross-species transmission of kobuviruses in Vietnam. Virus Evol 4:vey002. https:// doi.org/10.1093/ve/vey002

Lukashev AN, Drexler JF, Belalov IS, Eschbach-Bludau M, Baumgarte S, Drosten C (2012) Genetic variation and recombination in Aichi virus. J Gen Virol 93:1226-1235. https://doi.org/10. 1099/vir.0.040311-0

McPhail JA, Ottosen EH, Jenkins ML, Burke JE (2017) The Molecular basis of Aichi virus 3A protein activation of phosphatidylinositol 4 Kinase III $\beta$, PI4KB, through ACBD3. Structure 25:121-131. https://doi.org/10.1016/j.str.2016.11.016

Melnick JL (1996) My role in the discovery and classification of the enteroviruses. Annu Rev Microbiol 50:1-24. https://doi.org/10. 1146/annurev.micro.50.1.1

Melnick JL, Chanock RM, Gelfand H, Hammon WM, Huebner RJ, Rosen L, Sabin AB, Wenner HA (1963) Picornaviruses: classification of nine new types. Science 141:153-154

Ng TF, Marine R, Wang C, Simmonds P, Kapusinszky B, Bodhidatta L, Oderinde BS, Wommack KE, Delwart E (2012) High variety of known and new RNA and DNA viruses of diverse origins in untreated sewage. J Virol 86:12161-12175. https://doi.org/10. 1128/JVI.00869-12

Nielsen AC, Gyhrs ML, Nielsen LP, Pedersen C, Böttiger B (2013) Gastroenteritis and the novel picornaviruses Aichi virus, Cosavirus, Saffold virus, and Salivirus in young children. J Clin Virol 57:239-242. https://doi.org/10.1016/j.jcv.2013.03. 015

Oberste MS, Maher K, Kilpatrick DR, Pallansch MA (1999) Molecular evolution of the human enteroviruses: correlation of serotype with VP1 sequence and application to picornavirus classification. J Virol 73:1941-1948

Oh DY, Silva PA, Hauroeder B, Diedrich S, Cardoso DD, Schreier E (2006) Molecular characterization of the first Aichi viruses isolated in Europe and in South America. Arch Virol 151:1199-1206. https://doi.org/10.1007/s00705-005-0706-7

Onosi O, Upfold NS, Jukes MD, Luke GA, Knox C (2019) The first molecular detection of Aichi virus 1 in raw sewage and mussels collected in South Africa. Food Environ Virol 1:96-100. https:// doi.org/10.1007/s12560-018-9362-4

Oshiki M, Miura T, Kazama S, Segawa T, Ishii S, Hatamoto M, Yamaguchi T, Kubota K, Iguchi A, Tagawa T, Okubo T, Uemura S, Harada H, Kobayashi N, Araki N, Sano D (2018) Microfluidic PCR amplification and MiSeq amplicon sequencing techniques for high-throughput detection and genotyping of human pathogenic rna viruses in human feces, sewage, and oysters. Front Microbiol 9:830. https://doi.org/10.3389/fmicb. 2018.00830

Otomaru K, Naoi Y, Haga K, Omatsu T, Uto T, Koizumi M, Masuda T, Yamasato H, Takai H, Aoki H, Tsuchiaka S, Sano K, Okazaki S, Katayama Y, Oba M, Furuya T, Shirai J, Katayama K, Mizutani T, Nagai M (2016) Detection of novel kobu-like viruses in Japanese black cattle in Japan. J Vet Med Sci 78:321-324. https://doi.org/10.1292/jvms.15-0447

Oude Munnink BB, Canuti M, Deijs M, de Vries M, Jebbink MF, Rebers S, Molenkamp R, van Hemert FJ, Chung K, Cotten M, 
Snijders F, Sol CJ, van der Hoek L (2014) Unexplained diarrhoea in HIV-1 infected individuals. BMC Infect Dis 14:22. https://doi.org/10.1186/1471-2334-14-22

Pankovics P, Boros Á, Kiss T, Reuter G (2014) Identification and complete ge-nome analysis of kobuvirus in faecal samples of European roller (Coracias garru-lus): for the first time in bird. Arch Virol 160:345-351. https://doi.org/10.1007/s00705-0142228-7

Patel M, Glass RI (2009) Gastrointestinal syndromes. In: Richman DD, Whitley RJ, Hayden F (eds) Clinical virology. ASM Press, Washington, pp 45-57

Pham NT, Khamrin P, Nguyen TA, Kanti DS, Phan TG, Okitsu S, Ushijima H (2007) Isolation and molecular characterization of Aichi viruses from faecal specimens collected in Japan, Bangladesh, Thailand, and Vietnam. J Clin Microbiol 45:2287-2288. https://doi.org/10.1128/JCM.00525-07

Phan TG, Kapusinszky B, Wang C, Rose RK, Lipton HL, Delwart EL (2011) The fecal viral flora of wild rodents. PLoS Pathog 7:e1002218. https://doi.org/10.1371/journal.ppat.1002218

Pinheiro LB, Coleman VA, Hindson CM, Herrmann J, Hindson BJ, Bhat S, Emslie KR (2012) Evaluation of a droplet digital polymerase chain reaction format for DNA copy number quantification. Anal Chem 84:1003-1011. https://doi.org/10. $1021 /$ ac202578x

Polo D, Vilariño ML, Manso CF, Romalde JL (2010) Imported mollusks and dissemination of human enteric viruses. Emerg Infect Dis 16:1036-1038. https://doi.org/10.3201/eid1606. 091748

Polo D, Varela MF, Romalde JL (2015) Detection and quantification of hepatitis A virus and norovirus in Spanish authorized shellfish harvesting areas. Int J Food Microbiol 193:43-50. https://doi. org/10.1016/j.ijfoodmicro.2014.10.007

Portes SA, de Mello Volotao E, Rose TL, Rocha MS, Xavier MTP, de Assis RM, Fialho AM, Rocha MS, Miagostovich MP, Gagliardi Leite JP, Carvalho-Costa FA (2015) Aichi virus positivity in HIV-1 seropositive children hospitalized with diarrheal disease. Curr HIV Res 13:325-331

Prevost B, Lucas FS, Goncalves A, Richard F, Moulin L, Wurtzer S (2015) Large scale survey of enteric viruses in river and waste water underlines the health status of the local population. Environ Int 79:42-50. https://doi.org/10.1016/j.envint.2015.03. 004

Rački N, Morisset D, Gutiérrez-Aguirre I, Ravnikar M (2014) Onestep RT- droplet digital PCR: a breakthrough in the quantification of waterborne RNA viruses. Anal Bioanal Chem 406:661-667. https://doi.org/10.1007/s00216-013-7476-y

Reuter G, Boldizsár A, Papp G, Pankovics P (2009) Detection of Aichi virus shedding in a child with enteric and extraintestinal symptoms in Hungary. Arch Virol 154:1529-1532. https://doi. org/10.1007/s00705-009-0473-y

Reuter G, Boros A, Pankovics P (2011) Kobuviruses-a comprehensive review. Rev Med Virol 21:32-41. https://doi.org/10.1002/ rmv. 677

Ribes JM, Montava R, Téllez-Castillo CJ, Fernández-Jiménez M, Buesa J (2010) Seroprevalence of Aichi virus in a Spanish population from 2007 to 2008. Clin Vacc Immunol 17:545-549. https://doi.org/10.1128/CVI.00382-09

Rivadulla E, Varela MF, Romalde JL (2017) Low prevalence of Aichi virus in mollus-can shellfish samples from Galicia (NW Spain). J Appl Microbiol 122:516-521. https://doi.org/10.1111/jam. 13363

Rivadulla E, Varela MF, Romalde JL (2019) Epidemiology of Aichi virus in fecal samples from outpatients with acute gastroenteritis in Northwestern Spain. J Clin Virol 118:14-19
Romalde JL, Estes MK, Szücs G, Atmar RL, Woodely CM, Metcalf TG (1994) In situ detection of hepatitis A virus in cell cultures and shellfish tissues. Appl Environ Microbio 60:1921-1926

Rosario K, Nilsson C, Lim YW, Ruan Y, Breitbart M (2009) Metagenomic analysis of viruses in reclaimed water. Environ Microbiol 11:2806-2820. https://doi.org/10.1111/j.1462-2920. 2009.01964.x

Sabin C, Füzik T, Škubník K, Pálková L, Lindberg AM, Plevka P (2016) Structure of Aichi virus 1 and its empty particle: clues towards kobuvirus genome release mechanism. J Virol 90:10800-10810. https://doi.org/10.1128/JVI.01601-16

Saikruang W, Khamrin P, Suantai B, Ushijima H, Maneekarn N (2014) Molecular detection and characterization of Aichivirus A in adult patients with diarrhea in Thailand. J Med Virol 86:983-987. https://doi.org/10.1002/jmv.23904

Sdiri-Loulizi K, Hassine M, Gharbi-Khelifi H, Sakly N, Chouchane S, Guediche MN, Pothier P, Aouni M, Ambert-Balay K (2009) Detection and genomic char-acterization of Aichi viruses in stool samples from children in Monastir, Tunisia. J Clin Microbiol 47:2275-2278. https://doi.org/10.1128/JCM.00913-09

Sdiri-Loulizi K, Hassine M, Aouni Z, Gharbi-Khelifi H, Sakly N, Chouchane S, Guédiche MN, Pothier P, Aouni M, Ambert-Balay K (2010) First molecular detection of Aichi virus in sewage and shellfish samples in the Monastir region of Tunisia. Arch Virol 155:1509-1513. https://doi.org/10.1007/s00705-010-0744-7

Sewlikar S, D'Souza DH (2017) Survival of hepatitis A virus and Aichi virus in cranberry-based juices at refrigeration $\left(4^{\circ} \mathrm{C}\right)$. Food Microbiol 62:251-255. https://doi.org/10.1016/j.fm.2016. 10.003

Sharma SK, Amy G (2010) Chapter 15: Natural treatment systems. In: Edzwald JK (ed) Water quality and treatment: a handbook on drinking water, 6th edn. American Water Works Association, McGraw Hill Inc, New York

Terio V, Bottaro M, Di Pinto A, Fusco G, Barresi T, Tantillo G, Martella V (2018) Occurrence of Aichi virus in retail shellfish in Italy. Food Microbiol 74:120-124. https://doi.org/10.1016/j.fm. 2018.02.013

Thongprachum A, Fujimoto T, Takanashi S, Saito H, Okitsu S, Shimizu H, Khamrin P, Maneekarn N, Hayakawa S, Ushijima H (2018) Detection of nineteen enteric viruses in raw sewage in Japan. Infect Genet Evol 63:17-23. https://doi.org/10.1016/j. meegid.2018.05.006

Tuthill TJ, Groppelli E, Hogle JM, Rowlands DJ (2010) Picornaviruses. Curr Top Microbiol Immunol 343:43-89. https://doi. org/10.1007/82_2010_37

van der Schaar HM, Dorobantu CM, Albulescu L, Strating JR, van Kuppeveld FJ (2016) Fat(al) attraction: picornaviruses usurp lipid transfer at membrane contact sites to create replication organelles. Trends Microbiol 24:535-546. https://doi.org/10. 1016/j.tim.2016.02.017

Vossen P (2001) Scientific advice in support to risk management with regard to BSE. Verh K Acad Geneeskd Belg 63:379-403

Wang X, Peng W, Ren J, Hu Z, Xu J, Lou Z, Li X, Yin W, Shen X, Porta C, Walter TS, Evans G, Axford D, Owen R, Rowlands DJ, Wang J, Stuart DI, Fry EE, Rao Z (2012) A sensor-adaptor mechanism for enterovirus uncoating from structures of EV71. Nat Struct Mol Biol 19:424-429. https://doi.org/10.1038/nsmb. 2255

Weiss J (2005) A review of clinical experience and recommendations for improving patient care. Cutis 75:32-38

Yamashita T, Sakae K (2003) Molecular biology and epidemiology of Aichi virus and other diarrhoeogenic enteroviruses. Perspectives in medical virology, vol 9. Elsevier, New York, pp 645-657. https://doi.org/10.1016/S0168-7069(03)09040-2

Yamashita T, Kobayashi S, Sakae K, Nakata S, Chiba S, Ishihara Y, Isomura $S$ (1991) Isolation of cytopathic small roundviruses with 
BS-C-1 cells from patients with gastroenteritis. J Infect Dis 164:954-957

Yamashita T, Sakae K, Ishihara Y, Isomura S, Utagawa E (1993) Prevalence of newly isolated, cytopathic small round virus (Aichi strain) in Japan. J Clin Microbiol 31:2938-2943

Yamashita T, Sakae K, Tsuzuki H, Suzuki Y, Ishikawa N, Takeda N, Miyamura T, Yamazaki S (1998) Complete nucleotide sequence and genetic organization of Aichi virus, a distinct member of the Picornaviridae associated with acute gastroenteritis in humans. J Virol 72:8408-8412

Yamashita T, Sugiyama M, Tsuzuki H, Sakae K, Suzuki Y, Miyazaki Y (2000) Application of a reverse transcription-PCR for identification and differentiation of Aichi virus, a new member of the Picornavirus family associated with gastroenteritis in humans. J Clin Microbiol 38:2955-2961

Yamashita T, Ito M, Tsuzuki H, Sakae K (2001) Identification of Aichi virus infection by measurement of immunoglobulin responses in an enzyme-linked immunosorbent assay. J Clin Microbiol 39:4178-4180. https://doi.org/10.1128/JCM.39.11. 4178-4180.2001

Yamashita T, Adachi H, Hirose E, Nakamura N, Ito M, Yasui Y, Kobayashi S, Minagawa H (2014) Molecular detection and nucleotide sequence analysis of a new Aichi virus closely related to canine kobuvirus in sewage samples. J Med Microbiol 63:715-720. https://doi.org/10.1099/jmm.0.070987-0

Yang S, Zhang W, Shen Q, Yang Z, Zhu J, Cui L, Hua X (2009) Aichi virus strains in children with gastroenteritis, China. Emerg Infect Dis 15:1703-1705. https://doi.org/10.3201/eid1510.090522

Zell R (2017) Picornaviridae-the ever-growing vírus family. Arch Virol 163:299-317. https://doi.org/10.1007/s00705-017-3614-8

Zhu L, Wang X, Ren J, Kotecha A, Walter TS, Yuan S, Yamashita T, Tuthill TJ, Fry EE, Rao Z, Stuart DI (2016) Structure of human Aichi virus and implications for receptor binding. Nat Microbiol 1:16150. https://doi.org/10.1038/nmicrobiol.2016.150 